\title{
System aukcyjny jako nowy sposób wspierania OZE
}

\section{The Auction System as a New Way to Promote Renewable Energy}

\begin{abstract}
Synopsis. W artykule dokonano analizy zarówno obowiązujących, jak i projektowanych aktów prawnych w zakresie promowania i wytwarzania energii ze źródeł odnawialnych. Model gospodarki energetycznej oparty na źródłach odnawialnych różnie jest realizowany w poszczególnych państwach. Przy coraz większym udziale OZE oraz poziomu celów na kolejne lata istotne jest aby osiagniete zostały one przy jak najniższym koszcie wsparcia ze środków publicznych. $Z$ tego względu wiele państw zdecydowało się na stopniowe przechodzenie na system aukcyjny, dający kontrolę kosztów, struktury i przyrostu mocy nowych instalacji OZE. Problemem badawczym jest ocena skuteczności systemu aukcyjnego na tle dotychczas stosowanych instrumentów, zarówno pod względem przyrostu nowych mocy wytwórczych, jak i kosztów osiagania zamierzonych celów. Zagadnienia te, ze wzgledu na krótki okres funkcjonowania nowego systemu nie zostały jeszcze właściwie rozpoznane. W opracowaniu wykorzystano dane pochodzace $\mathrm{z}$ lat 2010-2018. Zakres przestrzenny obejmował głównie Polskę, ale również posłużono się przykładami pochodzącymi z innych państw na świecie. W badaniach i analizach posłużono się metodą porównawczą oraz zestawieniem poszczególnych technologii wytwarzania energii odnawialnej według analizowanych wartości. Przyjeto hipoteze, że system aukcyjny oparty na zasadach konkurencyjnych, skuteczniej i przy niższym wsparciu środków publicznych pozwoli osiaggać cele związane z promocją odnawialnych źródeł energii.

Celem artykułu jest przedstawienie dotychczasowego i nowego systemu wsparcia OZE, cen uzyskiwanych w aukcjach oraz pierwszych doświadczeń $\mathrm{z}$ jego wprowadzenia. Materiałem badawczym były materiały statystyczne Eurostatu i GUS-u, dokumenty Komisji Europejskiej, Ministerstwa Energii, Urzędu Regulacji Energetyki, raporty dotyczące systemów wsparcia z krajów europejskich i Polski. Metody badawcze wykorzystane w pracy to analizy dokumentów, aktów normatywnych, kolejnych nowelizacji ustawy o odnawialnych źródłach energii oraz wydanych na ich podstawie rozporządzeń. Dokonano również oceny i rozpoznanie poziomu wsparcia w systemie aukcyjnym w państwach, które już od wielu lat stosuja ten instrument. Analizy te pozwoliły ocenić dotychczasowe efekty przeprowadzonych aukcji, ich zalety i wady, sformułować wnioski w zakresie zmian organizacyjnych zapewniających sprawne funkcjonowanie systemu aukcyjnego.
\end{abstract}

Slowa kluczowe: odnawialne źródła energii, system aukcyjny, rynek OZE

Abstract. The article analyzes both existing and proposed legal acts in the field of promoting and generating energy from renewable sources. The model of energy management based on renewable sources is implemented differently in individual countries. With the increasing share of renewable energy and the level of objectives for the coming years, it is essential that they are achieved with the lowest possible cost of support from public funds. For this reason, many countries have decided to gradually move to the auction system, giving control over the costs, structure and capacity increase of new RES installations. The research problem is the evaluation of the effectiveness of the auction system against the background of the instruments used so far, both in terms of the increase in new generation capacities and the costs of achieving the intended objectives. These issues, due to the short period of functioning of the new system, have not been properly identified yet. The study uses data from the years 2010-2018. The spatial range was mainly in Poland, but examples from other countries around the world were also used. The research and analysis used a comparative method and a list of

\footnotetext{
${ }^{1}$ dr inż.; Wydział Nauk Ekonomicznych Politechniki Koszalińskiej, ul. Kwiatkowskiego 6E, 75-343 Koszalin, e-mail:waldemar.gostomczyk@tu.koszalin.pl; https://orcid.org/0000-0003-1357-7493
} 


\begin{abstract}
individual renewable energy production technologies according to the analyzed values. It has been hypothesized that an auction system based on competitive principles, more effectively and with lower support of public funds will allow for achieving goals related to the promotion of renewable energy sources.

The aim of the article is to present the current and new RES support system, prices obtained in auctions and the first experience in its implementation. The research material were Eurostat and GUS statistical materials, documents from the European Commission, the Ministry of Energy, the Energy Regulatory Office, reports on support systems from European countries and Poland. Research methods used in the work include analysis of documents, normative acts, subsequent amendments to the Act on renewable energy sources and regulations issued on their basis. The assessment and recognition of the level of support in the auction system in countries that have been using this instrument for many years was also made. These analyses allowed the assessment of the effects of the auctions carried out, their advantages and disadvantages, and helped formulate conclusions in the field of organizational changes ensuring efficient functioning of the auction system.
\end{abstract}

Key words: renewable energy sources, auction system, renewable energy market

JEL Classification: O13, Q42, Q48

\title{
Wprowadzenie
}

Dobór odpowiedniego wsparcia ma zasadnicze znaczenie dla rozwoju odnawialnych źródeł energii (OZE), ich ilości i struktury, uzyskania wysokiej efektywności wydatkowania środków publicznych i stabilizacji całego systemu energetycznego. System zielonych certyfikatów wprowadzony w 2005 roku, zachęcający inwestorów do lokowania kapitału w inwestycje OZE spełnił swoją funkcję. Jego rezultatem był coroczny wzrost udziału energii odnawialnej $\mathrm{w}$ miksie energetycznym, rokującym spełnienie unijnych zobowiązań. Na świecie rządy poszczególnych państw stale poszukują bardziej efektywnych i skuteczniejszych systemów wsparcia pozwalających osiagnąć wytyczone cele niższym kosztem. Wprowadzone w Polsce pod koniec 2016 roku aukcje na energię z OZE stają się jednym $\mathrm{z}$ dostępnych instrumentów prawnych do realizacji nowych inwestycji OZE, które dla większości technologii mogą zapewnić opłacalność inwestycji w nowe źródła (Rynek aukcji, 2018).

Model gospodarki energetycznej oparty na źródłach odnawialnych różnie jest realizowany w poszczególnych państwach. Rozwój OZE to trend ogólnoświatowy i ze względu na wytyczone cele w zakresie ochrony środowiska nieodwracalny, zwłaszcza w państwach należących do Unii Europejskiej. W czerwcu 2018 roku decydenci UE uzgodnili cel zwiększenia udziału odnawialnych źródeł energii $\mathrm{w}$ unijnym miksie energetycznym do 2030 r. do $32 \%$. Jednak w przeciwieństwie do celu na rok $2020-$ w ramach którego wyznaczono indywidualne, obligatoryjne cele dla każdego kraju UE (dla Polski $15 \%$ ), które mają złożyć się razem na cel unijny na poziomie $20 \%$ - unijne uzgodnienia co do celu OZE na rok 2030 nie przewidują wprowadzenia obowiązkowych celów krajowych. Tym co ma zapewnić realizację celu OZE na 2030 r. - wobec obecnie obowiązkowych, krajowych celów są regulacje dotyczące governanse. Ich podstawą maja być tworzone w latach 2021-2030 i aktualizowane co roku krajowe plany na rzecz energii i klimatu. Zdaniem Komisji Europejskiej, regulacje dotyczące governanse mają dać inwestorom pewność co do warunków otoczenia prawnego i ekonomicznego, w których będą realizowane inwestycje energetyczne w poszczególnych krajach UE (portal Gram w zielone pl.). Istotną częścią tych regulacji jest system aukcyjny na który przechodzi coraz 
więcej państw UE. Koszty wspierania odnawialnych źródeł energii są coraz wyższe. Przy coraz większym udziale OZE oraz rosnących celów na kolejne lata istotne jest aby osiagnięte zostały one przy jak najniższym koszcie wsparcia ze środków publicznych. Z tego względu wiele państw zdecydowało się na stopniowe przechodzenie na system aukcyjny, dający kontrolę kosztów, struktury i przyrostu mocy nowych instalacji OZE.

Odnawialne źródła energii to bardzo zróżnicowana grupa nośników dająca energię elektryczną, cieplną $\mathrm{i}$ wykorzystywaną $\mathrm{w}$ transporcie. Charakteryzują się one również zróżnicowanym poziomem postępu technologicznego przekładającego się na koszty inwestycyjne i eksploatacyjne. Zróżnicowanie kosztów produkcji energii pochodzącej $\mathrm{z}$ różnych źródeł jest podstawą odmiennego traktowania w zakresie cen referencyjnych dla poszczególnych koszyków technologicznych.

Obecnie o wykorzystaniu OZE najczęściej mówimy w kategoriach korzyści dla ochrony środowiska. Jednak przy odpowiedniej skali produkcji i rozwoju przemysłów wytwarzających urządzenia do produkcji energii odnawialnej, uzyskujemy również wymierne efekty w postaci wzrostu PKB i zatrudnienia, zwiększenia wpływów do budżetu centralnego i lokalnego, zwiększenia bezpieczeństwa energetycznego w skali kraju i regionu oraz przede wszystkim z pozytywnym oddziaływaniem na klimat. Według portalu Gramwzielone.pl tylko branża wiatrowa w Europie dokłada do PKB Unii Europejskiej około 36 mld euro rocznie, tworząc około 263 tys. miejsc pracy oraz wypracowuje co roku eksport warty około 8 mld euro. Rozwój ten szczególnie uwidacznia się na obszarach wiejskich, gdzie instalowana jest większość urządzeń wykorzystujących OZE. W skali lokalnej to przede wszystkim wzrost wpływów podatkowych, zwiększenie zatrudnienia, rozwój rynku produkującego surowce dla instalacji OZE (biogazownie, lokalne kotłownie), zwiększenie bezpieczeństwa i samodzielności energetycznej w skali lokalnej.

Celem artykułu jest przedstawienie dotychczasowego i nowego systemu wsparcia OZE, cen uzyskiwanych na aukcjach oraz pierwszych doświadczeń z jego wprowadzenia. Na ich podstawie poczyniono próby oceny wpływu nowych mechanizmów ekonomicznych na decyzje inwestorów dotyczących mocy i struktury odnawialnych źródeł. Materiałem badawczym były dane statystyczne Eurostatu i GUS-u, dokumenty Komisji Europejskiej, Ministerstwa Energii, Urzędu Regulacji Energetyki, raporty dotyczące systemów wsparcia z krajów europejskich i Polski. Metody badawcze wykorzystane w pracy to analizy dokumentów, aktów normatywnych, kolejnych nowelizacji ustawy o odnawialnych źródłach energii oraz wydanych na ich podstawie rozporządzeń. Analizy te pozwoliły ocenić dotychczasowe efekty przeprowadzonych aukcji, ich zalety i wady, sformułować wnioski wzakresie zmian organizacyjnych zapewniających sprawne funkcjonowanie systemu aukcyjnego. Skuteczność systemu aukcyjnego przejawia się przede wszystkim obniżką cen wynikająca z konkurencji pomiędzy producentami, inwestorami oraz w ramach poszczególnych technologii.

\section{Rynek energii odnawialnej w UE i w Polsce}

Analiza ilościowa rynku energii odnawialnej pozwala ocenić jego strukturę oraz dynamikę wzrostu w poszczególnych technologiach. Sytuacja na rynku odnawialnych źródeł energii w poszczególnych krajach UE jest bardzo zróżnicowana. Wynika ona z historycznych zaszłości, lokalnych uwarunkowań oraz skuteczności prowadzonej polityki względem inwestorów w OZE. Według unijnej agencji statystycznej Eurostat udział OZE w unijnym miksie konsumpcji energii elektrycznej, cieplnej i w transporcie wyniósł w 2016 roku 17\% 
(16,7\% w roku 2015), wobec unijnego celu na rok 2020, który wynosi 20\%. Największy udział w tym miksie posiada Szwecja - 53,8\%, Finlandia - 38,7\% i Łotwa 37,2\%. Wynika on przede wszystkim z dobrych warunków dla rozwoju hydroenergetyki i dużych zasobów biomasy leśnej. Najniższy udział odnotował Luksemburg - 5,4\%, Malta - 6\% i Holandia $6 \%$. Najdalej od wywiązania się z celu udziału energii odnawialnej w krajowych miksach energetycznych w 2016 roku była Francja (16\% wobec celu $23 \%$, Irlandia (9,5\% wobec celu 16\% i Wielka Brytania (9,3\% wobec 15\%) (Energy statistic, 2017).

Według Eurostatu w 2016 roku w Polsce udział OZE w miksie konsumpcji energii spadł do 11,3\% w stosunku do $11,7 \%$ w roku 2015 i wobec 11,5\% w roku 2014 (Energy balance 2017). Oznacza to, że od dwóch lat procentowy udział energii odnawialnej w Polsce zmniejsza się. Zahamowanie wzrostu udziału energii odnawialnej jest konsekwencją spadku wykorzystania biomasy w ramach współspalania, spowodowanym znaczącym obniżeniem cen zielonych certyfikatów. Cel, który Polska powinna osiagnąć w 2020 r. wynosi $15 \%$. Do spełnienia celu brakuje jeszcze 3,7\%. Jak podaje GUS, w krajowym pozyskaniu i wykorzystaniu energii ze źródeł odnawialnych dominują paliwa stałe. Ich udział w pozyskaniu energii ze źródeł odnawialnych w 2016 r. stanowił 70,74\%. Udział energii wiatrowej wynosił $11,93 \%$, biopaliw ciekłych $10,16 \%$, biogazu $2,88 \%$, energii wodnej $2,03 \%$, odpadów komunalnych $0,85 \%$, pomp ciepła i energii słonecznej po $0,58 \%$, a energii geotermalnej 0,28\%. Produkcja energii elektrycznej z odnawialnych źródeł energii wyniosła w 2016 r. ogółem 22,807 TWh wobec 22,684 TWh w roku 2015 i 19,841 TWh w roku 2014. W 2016 roku najwięcej odnawialnej energii elektrycznej wyprodukowano z wiatru $(12,587 \mathrm{TWh})$. Oznacza to 3-krotny wzrost produkcji w stosunku do roku 2012. Spadła natomiast produkcja energii elektrycznej z biopaliw stałych $(6,912 \mathrm{TWh}$ wobec 9,026 TWh w roku 2015). Pozostałe źródła zielonej energii w 2016 roku to energetyka wodna - 2,139 GWh, biogaz - 1,027 TWh, technologie energii słonecznej - 123,9 GWh. W ciepłownictwie największy udział w wytwarzaniu energii z OZE miały w 2016 r. biopaliwa stałe - 95,67\%, biogaz - 4,21\% i odpady komunalne - 0,11\% (Energia, 2017). Udział energii odnawialnej w Polsce mógłby być znacznie wyższy. Na jej poziom wpływają zarówno uregulowania prawne jak i ekonomiczne. Z przyczyn ekonomicznych należy wymienić spadek opłacalności spowodowany znaczącym obniżeniem cen zielonych certyfikatów. Dla zahamowania wysokiej dynamiki przyrostu zainstalowanej mocy w instalacjach wiatrowych na lądzie negatywny wpływ miała zmiana stanu prawnego dotycząca ich opodatkowania, polegająca na jego objęciem całej konstrukcji a nie jak wcześniej tylko części. W rezultacie wzrostu obciążeń podatkowych w 2017 r. $70 \%$ farm wiatrowych było deficytowych. Wprowadzenie systemu aukcyjnego i wprowadzone ceny referencyjne stwarzają dla tych technologii możliwość poprawy wyniku finansowego.

\section{Systemy wsparcia OZE}

W żadnym kraju rozwój OZE nie odbywa się bez wsparcia finansowego, organizacyjnego i politycznego. Kraje UE, które obecnie przodują w ilości i dynamice wzrostu udziału OZE w przeszłości zdecydowały się na przeznaczenie znacznych środków publicznych w ramach różnych systemów wsparcia.

Formy wspierania inwestycji w sektorze OZE dzielimy na dwa podstawowe systemy:

1. System ksztaltowania cen. Obejmuje on system dopłat i cen gwarantowanych, gwarancje zbytu, pomoc publiczną w postaci dotacji, kredytów, pożyczek, ulgi 
podatkowe. Taryfy gwarantowane (feed-in tariffs- FIT) polegają na zagwarantowaniu przez regulatora stałej ceny za wyprodukowanie energii elektrycznej z OZE. Jej wysokość ustalana jest m.in. na podstawie zastosowanej technologii, lokalizacji obiektu, a także daty rozpoczęcia produkcji energii. W systemie FIT energia trafia bezpośrednio do operatora, który ma obowiązek z urzędu do jej zakupu. System zielonych certyfikatów polega natomiast na zobligowaniu określonych podmiotów do wyprodukowania energii przy wykorzystaniu OZE, bądź zakupie certyfikatów, które pełnią w nim gwarancje pochodzenia energii. W sytuacji gdy przedsiębiorstwo nie wyprodukowało wystarczającej ilości energii z OZE lub nie nabyło wymaganej ilości certyfikatów, Urząd Regulacji Energetyki (URE) nakłada kary zastępcze.

2. System ksztaltowania ilości wytworzonej energii z OZE. Kształtuje on podaż OZE uzyskaną dzięki przetargom, aukcjom z gwarancją zakupu przez 15-20 lat określonej ilości energii po cenie zaoferowanej $\mathrm{w}$ aukcji niższej niż ceny referencyjne dla określonej technologii wytwarzania.

Tabela 1. Podstawowe różnice pomiędzy systemami wsparcia

Table 1. Basic differences between support systems

\begin{tabular}{|c|c|c|}
\hline Zagadnienia & System aukcyjny & System świadectw pochodzenia \\
\hline Czas wsparcia & 15 lat & 15 lat \\
\hline $\begin{array}{l}\text { Ceny energii } \\
\text { elektrycznej }\end{array}$ & $\begin{array}{l}\text { Stała cena zaoferowana w aukcji indeksowana } \\
\text { o wskaźnik inflacji przez cały okres wsparcia }\end{array}$ & $\begin{array}{l}\text { Stała cena ogłaszana kwartalnie przez Prezesa } \\
\text { URE }\end{array}$ \\
\hline $\begin{array}{l}\text { Cena praw } \\
\text { majątkowych }\end{array}$ & brak & $\begin{array}{l}\text { Cena zmienna podlegająca regułom } \\
\text { rynkowym, prawa majątkowe są przedmiotem } \\
\text { obrotu giełdowego na Towarowej Giełdzie } \\
\text { Energii }\end{array}$ \\
\hline $\begin{array}{l}\text { Zróżnicowanie } \\
\text { wsparcia }\end{array}$ & $\begin{array}{l}\text { Na podstawie koszyków technologicznych } \\
\text { uwzględniających rodzaj źródła energii, zainstalowaną } \\
\text { moc, stopień redukcji emisji } \mathrm{CO}_{2} \text { oraz stopnia } \\
\text { wykorzystania mocy }\end{array}$ & Jednolite zasady dla wszystkich źródeł OZE \\
\hline $\begin{array}{l}\text { Przystapienie do } \\
\text { systemu }\end{array}$ & $\begin{array}{l}\text { Na podstawie zgłoszeń na platformie internetowej, } \\
\text { według wymogów regulaminu aukcji }\end{array}$ & $\begin{array}{l}\text { Na podstawie uzyskanej koncesji lub wpisu do } \\
\text { rejestru małych instalacji OZE (do } 200 \mathrm{~kW}) \text {, } \\
\text { wniosek o wydanie praw majątkowych } \\
\text { potwierdzonych przez OSD }\end{array}$ \\
\hline Kary w systemie & $\begin{array}{l}\text { Kary pieniężna w przypadku w przypadku braku } \\
\text { rozliczenia zadeklarowanej ilości wytworzonej energii } \\
\text { z instalacji OZE. Kara ta wynika z art. } 168 \text { ust. } 15 \\
\text { ustawy z dnia } 20 \text { lutego } 2015 \text { r. o odnawialnych } \\
\text { źródłach energii (Dz. U. poz. 478, z późn. zm.), } \\
\text { polegająca na ukaraniu wytwórcy OZE w przypadku } \\
\text { braku rozliczenia zadeklarowanej ilości wytworzenia } \\
\text { energii elektrycznej z instalacji OZE w okresach } \\
\text { trzyletnich. Kara ta będzie naliczana, jeżeli faktyczna } \\
\text { produkcja wyniesie mniej niż 85\% wartości } \\
\text { zaoferowanej w systemie aukcyjnym, a jej wysokość to } \\
\text { 50\% wartości wynikającej z iloczynu ceny złożonej w } \\
\text { ofercie i różnicy pomiędzy ilością energii planowaną } \\
\text { do wytworzenia i złożoną w ofercie a faktyczną } \\
\text { produkcją. }\end{array}$ & Brak kar \\
\hline $\begin{array}{l}\text { Zakres kontroli } \\
\text { przyrostu } \\
\text { zainstalowanej } \\
\text { mocy }\end{array}$ & $\begin{array}{l}\text { Pełna kontrola ilości i struktury instalacji OZE na } \\
\text { podstawie ogłaszanych przetargów }\end{array}$ & $\begin{array}{l}\text { Obowiązek, nakładany na przedsiębiorstwa } \\
\text { obrotu energią, zakupu energii z OZE w celu } \\
\text { utrzymania ustalonego udziału zielonej energii } \\
\text { w całkowitej ilości energii sprzedawanej do } \\
\text { odbiorców końcowych }\end{array}$ \\
\hline
\end{tabular}

Źródło: opracowanie na podstawie Ustawy OZE oraz Regulaminu Aukcji. 
Podstawową przyczyną zmian systemu wsparcia OZE w Polsce są problemy funkcjonowania rynku zielonych certyfikatów. Problemy te związane są z występująca od 2012 roku nadpodaży certyfikatów, głównie ze strony wytwórców stosujących technologie współspalania (jednoczesne spalanie węgla i biomasy). Nadpodaż ta na koniec 2016 roku wynosiła $21913 \mathrm{GWh}$, co bezpośrednio przełożyło się na ceny certyfikatów i spadające przychody inwestorów (z ok. 500 zł/MWh w roku 2011 do ok. 200 zł/MWh na początku 2017 roku (Stan energetyki..., 2017).

W latach 2005-2016 według wyliczeń WiseEuropa koszt systemu zielonych certyfikatów wyniósł ok. $30 \mathrm{mld}$ zł. Z tego około 10,2 mld zł to były dopłaty do produkcji energii elektrycznej ze współspalania biomasy z węglem, a następne 6 mld zł wsparło właścicieli starych elektrowni wodnych. Łącznie w latach 2005-2016 wsparcie dla energetyki odnawialnej w Polsce wyniosło około 33,6 mld zł.

Według art. 69a. Ustawy o OZE wersji z kwietnia 2018 r. energia elektryczna wytworzona w danej instalacji odnawialnego źródła energii może korzystać z:

1) systemu wsparcia świadectw pochodzenia albo

2) systemu wsparcia świadectw pochodzenia biogazu rolniczego, albo

3) systemu wsparcia, o którym mowa w art. 70a-70f, albo

4) aukcyjnego systemu wsparcia.

Zgodnie z art. 80 ust. 1 i 2 aukcję wygrywają uczestnicy aukcji:

1) którzy zaoferowali najniższą cenę sprzedaży energii elektrycznej z odnawialnych źródeł energii, pomniejszoną o kwotę podatku od towarów i usług oraz

2) których oferty łącznie nie przekroczyły 100\% wartości energii elektrycznej z odnawialnych źródeł energii określonej w ogłoszeniu o aukcji i 80\% ilości energii elektrycznej objętej wszystkimi ofertami.

Główną zaletą systemu aukcyjnego jest, że gwarantuje zwycięzcom aukcji sprzedaż energii po stałej cenie przez cały piętnastoletni okres wsparcia, niezależnie od przyszłych warunków rynkowych. Uczestnicy aukcji dla instalacji już istniejących i zmodernizowanych mają możliwość zgłaszania niższych cen ponieważ dotychczas otrzymana pomoc odliczana jest od całkowitej sumy wsparcia finansowego przewidzianego w okresie 15 lat.

\section{System wsparcia jako element pomoc publicznej}

W komunikacie z dnia 6 czerwca 2012 r. zatytułowanym „Energia odnawialna: ważny uczestnik europejskiego rynku energii” (COM(2012)027) Komisja Europejska wskazała obszary, w których do 2020 roku trzeba dołożyć większych starań, by produkcja energii ze źródeł odnawialnych w UE stale wzrastała. W listopadzie 2013 r. Komisja przedstawiła dalsze wytyczne dotyczące systemów wsparcia energii ze źródeł odnawialnych aby cele te osiągnąć jak najmniejszym kosztem (COM(2013)7243). Przeprowadzony przegląd dotacji, jakie państwa członkowskie stosowały w przeszłości pozwoliły sformułować wnioski dotyczące preferencyjnego stosowania systemu aukcyjnego w kolejnych etapach kształtowania nowych ram systemów wsparcia energii ze źródeł odnawialnych zawartych w dokumencie „Wytyczne w sprawie pomocy państwa na ochronę środowiska i cele związane z energią w latach 2014-2020" (2014/C 200/01).

W dniu 13 grudnia 2017 r. Komisja Europejska opublikowała komunikat dotyczaccy zatwierdzenia - na mocy przepisów UE w dziedzinie pomocy państwa - polskiego programu wsparcia energii ze źródeł odnawialnych. W ramach programu, którego wartość 
szacuje się na 40 mld PLN (około 9,4 mld EUR) producentom energii ze źródeł odnawialnych zostanie przyznana pomoc państwa za pośrednictwem konkurencyjnych aukcji. Pomoc ta zgodnie $\mathrm{z}$, Wytycznymi $\mathrm{w}$ sprawie pomocy państwa na ochronę środowiska na cele związane z energią w latach 2014-2020 (Dz. Urz. UE seria C, nr 200, s. 1) ma gwarantować, że wykorzystanie funduszy publicznych jest ograniczone i że nie występuje nadmierna kompensacja.

Decyzja ta umożliwiła Ministerstwu Energii prowadzenie zmian w regule kumulacji łącznej pomocy uzyskanej przez wytwórców energii z OZE oraz w mechanizmie zapewnienia konkurencyjności składanych ofert aukcyjnych. Kwestia pomocy publicznej budzi najwięcej wątpliwości wśród potencjalnych uczestników aukcji. Zagadnienia związane z pomocą publiczną zawarte $\mathrm{w}$ art. 39 ustawy OZE wskazują że łączna wartość pomocy publicznej dla wytwórcy zamierzającego brać udział w aukcji OZE, nie może przekroczyć określonego pułapu, stanowiącego różnicę między ilością energii wytworzonej $\mathrm{z}$ danej instalacji OZE w okresie 15 lat, pomnożoną przez cenę referencyjną właściwą dla danej technologii, a przychodami ze sprzedaży tej samej ilości energii według średniej ceny sprzedaży energii elektrycznej na rynku konkurencyjnym, obowiązującej w dniu złożenia oferty. Przekroczenie tej łącznej pomocy publicznej skutkuje tym, że dany wytwórca nie może przystąpić do aukcji OZE. Maksymalny poziom łącznej pomocy publicznej został określony na takim poziomie aby wytwórca zamierzający wystartować $\mathrm{w}$ aukcji zaproponował całą ilość wytworzonej przez siebie energii po maksymalnej do uzyskania cenie. Wytwórca musi jednak kalkulować zaproponowany przez siebie poziom cen, za wytworzoną $\mathrm{w}$ instalacji OZE energię elektryczna, aby nie przekroczyła ona poziom konkurentów, ponieważ co do zasady konkurencyjnego charakteru aukcji wygrywają ci, którzy zaproponują jak najniższą cenę za wytworzoną energię (Czysta energia - nr 1/2016).

Przykład obliczania wartości pomocy publicznej w systemie aukcyjnym:

1. Prognozowana wartość ceny referencyjnej dla istniejącej elektrowni OZE -

$172,22 \mathrm{zł} / \mathrm{MWh}+238,83 \mathrm{zł} / \mathrm{MWh}=411,05 \mathrm{zz} / \mathrm{MWh}$

2. Wartość pomocy publicznej dla inwestora $-188 \mathrm{zz} / \mathrm{MWh}$

3. Maksymalna wartość energii możliwa do zaoferowania dla inwestora -

$411,05 \mathrm{zł} / \mathrm{MWh}-188 \mathrm{zz} / \mathrm{MWh}=223,05 \mathrm{zz} / \mathrm{MWh}$

Nowe zasady pomocy publicznej preferują inwestorów, którzy dopiero planują wybudować nowe instalacje wykorzystujące odnawialne źródła energii. W tym przypadku uzyskiwane ceny będą zbliżone do cen referencyjnych lub uzyskanych $\mathrm{w}$ ramach przetargu. W sytuacji instalacji już funkcjonujących decyzja o udziale w aukcji zależeć będzie od kalkulacji uwzględniającej dotychczas uzyskaną pomoc w postaci dotacji, sprzedaży zielonych certyfikatów czy dopłat do kredytów. Im starsza inwestycja, tym warunki przejścia do systemu aukcyjnego są mniej korzystne. Ci, którzy jednak zdecydują się na przejście, mogą zaproponować ceny niższe od referencyjnych, co zwiększa prawdopodobieństwo wygrania aukcji.

\section{Rodzaje aukcji}

Aukcje, przy stosunkowo krótkim okresie funkcjonowania, nie mają jednorodnej postaci. Ich zróżnicowanie uwzględnia ustawa o odnawialnych źródłach energii a ich część jest konsekwencją dostosowywania do zmiennych warunków rynkowych. Na podstawie przeglądów systemów aukcyjnych funkcjonujących w krajach unijnych zauważalna jest ich 
elastyczność i wielość form. Niżej wymieniono najczęściej występujące w krajach UE rodzaje aukcji:

Aukcje „migracyjne” - aukcje dla instalacji funkcjonujących w systemie zielonych certyfikatów, które wyrażają wolę przejścia do systemu aukcyjnego.

Aukcje dla instalacji modernizowanych - dla instalacji OZE, które w wyniku modernizacji uzyskują przyrost mocy lub poniesione nakłady są nie mniejsze niż $30 \%$ wartości początkowej.

Aukcje dla instalacji nowo tworzonych - budowanych po przeprowadzeniu aukcji.

Aukcje dla wydzielonych koszyków technologicznych - na przykład oddzielnie dla instalacji fotowoltaicznych i wiatrowych.

Aukcje dla kilku koszyków technologicznych - W Niemczech ogłoszono aukcje dla odnawialnych źródeł energii, w której o wsparcie konkurują inwestorzy planujący budowę elektrowni wiatrowych i fotowoltaicznych. Ma ona stworzyć konkurencje między energetyką wiatrową i słoneczną i przyśpieszyć spadek cen energii odnawialnej (Informator Federalnej agencji Bundesnetzagentur - BnetzA, 2017).

Aukcje transgraniczne - dotyczą one przede wszystkim budowanych farm morskich. Na przykład w aukcjach duńskich uczestniczą inwestorzy niemieccy a w aukcjach niemieckich inwestorzy z Danii.

Aukcje uwzględniające miejsce lokalizacji instalacji - na przykład we Francji przeprowadzono oddzielne aukcje dla instalacji fotowoltaicznych dachowych i gruntowych oraz oddzielnie dla instalacji we Francji i ich terytoriów zamorskich. W Niemczech z kolei przeprowadzane są aukcje dla wybranych landów.

Aukcja zwykła - aukcja o której mowa w art. 73 Ustawy OZE, do której nie mają zastosowania przepisy art. 80 ust.4-8 i 11 tej ustawy. W praktyce obejmują one instalacje OZE z wyłączeniem źródeł wykorzystujących różne źródła biomasy.

Aukcja interwencyjna - aukcja o której mowa w art. 80 - ust. 4 Ustawy OZE na zakup lub wytwarzanie energii elektrycznej, z gwarancją pokrycia ujemnego salda, o którym mowa w art.92 ust.5.

W Polsce przeprowadzone dotychczas nielicznie aukcje uwzględniały: instalacje nowe i już funkcjonujące, aukcje migrujące oraz aukcje dla wydzielonych koszyków technologicznych. W przyszłości celowe byłoby jednoczesne przeprowadzenie aukcji dla kilku koszyków technologicznych, co przyczyniłoby się do wzrostu konkurencyjności i obniżki cen oferowanych na aukcji.

\section{Przepisy prawne regulujące funkcjonowanie systemu aukcyjnego}

Znowelizowana 29 grudnia 2015 roku oraz 22 czerwca 2016 roku Ustawa o OZE w rozdziale 4 wprowadziła nowe przepisy o systemie wsparcia, tj. system aukcyjny - jako podstawowy i wyłączny system wsparcia dla wszystkich nowych instalacji OZE, które zwyciężą w aukcjach. Przepisy te weszły w życie 1 lipca 2016 roku (Ustawa o OZE, 2015; 2017). Wprowadzenie systemu aukcyjnego nie zakończyło działań dotychczasowego systemu wsparcia dla OZE opartego na dwóch głównych filarach: (a) systemie zbywalnych praw majątkowych $\mathrm{w}$ formie świadectw pochodzenia (tzw. „zielonych certyfikatów”, wydawanych za megawatogodzinę energii wyprodukowanej przez instalację OZE, oraz (b) obowiązku zakupu energii wyprodukowanej w instalacjach OZE przez sprzedawców $\mathrm{z}$ urzędu (Stan energetyki wiatrowej, 2017). 
Tabela 2. Ceny referencyjne dla aukcji OZE w latach 2016-2018

Table 2. Reference prices for RES auctions in 2016-2018

\begin{tabular}{|c|c|c|c|c|}
\hline \multirow[b]{2}{*}{ L.p. } & \multirow[b]{2}{*}{ Typ instalacji } & \multicolumn{3}{|c|}{ Wartość referencyjna w zł/MWh } \\
\hline & & 2016 & 2017 & $\begin{array}{l}2018(\mathrm{wg} \\
\text { projektu z X } \\
2017 \mathrm{r} \text {. }\end{array}$ \\
\hline 1. & $\begin{array}{l}\text { lącznej mocy zainstalowanej elektrycznej nie większej niż } 1 \mathrm{MW}, \\
\text { wykorzystujących wyłącznie biogaz rolniczy do wytwarzania energii } \\
\text { elektrycznej }\end{array}$ & 550 & 550 & 570 \\
\hline 2. & $\begin{array}{l}\text { łącznej mocy zainstalowanej elektrycznej większej niż } 1 \mathrm{MW} \text {, } \\
\text { wykorzystujaccych wyłącznie biogaz rolniczy do wytwarzania energii } \\
\text { elektrycznej }\end{array}$ & 550 & 550 & 550 \\
\hline 3. & $\begin{array}{l}\text { wykorzystujacych wyłacznie biogaz pozyskany ze składowisk odpadów do } \\
\text { wytwarzania energii elektrycznej }\end{array}$ & 305 & 405 & 425 \\
\hline 4. & $\begin{array}{l}\text { wykorzystujacych wyłacznie biogaz pozyskany z oczyszczalni ścieków do } \\
\text { wytwarzania energii elektrycznej }\end{array}$ & 335 & 365 & 385 \\
\hline 5. & $\begin{array}{l}\text { wykorzystujących wyłącznie do wytwarzania energii elektrycznej biogaz inny } \\
\text { niż określony w pkt. } 3 \text { i } 4\end{array}$ & 340 & 355 & 385 \\
\hline 6. & $\begin{array}{l}\text { łącznej mocy zainstalowanej elektrycznej nie wiekkszej niż } 50 \mathrm{MW} \text {, } \\
\text { wykorzystujących do wytwarzania energii elektrycznej biomase spalaną w } \\
\text { dedykowanej instalacji spalania biomasy lub układach hybrydowych } \\
\text { wykorzystujacych do wytwarzania energii elektrycznei biomase, biopłyny. }\end{array}$ & 415 & 415 & 415 \\
\hline 7. & $\begin{array}{l}\text { biogaz lub biogaz rolniczy spalany w dedykowanej instalacji spalania } \\
\text { wielopaliwowego }\end{array}$ & 310 & 325 & 325 \\
\hline 8. & $\begin{array}{l}\text { łącznej mocy zainstalowanej elektrycznej nie wiekkszej niż } 50 \mathrm{MW} \text {, w } \\
\text { dedykowanej instalacji spalania biomasy lub układach hybrydowych, w } \\
\text { wysokosprawnej kogeneracji }\end{array}$ & 435 & 450 & 450 \\
\hline 9. & $\begin{array}{l}\text { łącznej mocy zainstalowanej elektrycznej wiekkszej niż } 50 \mathrm{MW} \text { i o mocy } \\
\text { osiagalnej cieplnej w skojarzeniu nie wiekkszej niż } 150 \mathrm{MWt} \text {, w dedykowanej } \\
\text { instalacji spalania biomasy lub układach hybrydowych, w wysokosprawnej } \\
\text { kogeneracji }\end{array}$ & 420 & 435 & 435 \\
\hline 10. & w instalacji termicznego przekształcania odpadów & 385 & 385 & 210 \\
\hline 11. & $\begin{array}{l}\text { wykorzystujących wyłącznie biopłyny do wytwarzania energii elektrycznej } \\
\text { łącznej mocy zainstalowanej elektrycznej nie większej niż } 1 \mathrm{MW} \text {, }\end{array}$ & 475 & 475 & 475 \\
\hline 12. & $\begin{array}{l}\text { wykorzystujaccych do wytwarzania energii elektrycznej wyłącznie energię } \\
\text { wiatru na lądzie }\end{array}$ & 300 & 320 & 310 \\
\hline 13. & $\begin{array}{l}\text { łącznej mocy zainstalowanej elektrycznej większej niż } 1 \mathrm{MW} \text {, } \\
\text { wykorzystujących do wytwarzania energii elektrycznej wyłącznie energię } \\
\text { wiatru na lądzie }\end{array}$ & 385 & 350 & 350 \\
\hline 14. & $\begin{array}{l}\text { łącznej mocy zainstalowanej elektrycznej nie większej niż } 1 \mathrm{MW} \\
\text { wykorzystujących wyłącznie hydroenergię do wytwarzania energii } \\
\text { elektrycznej }\end{array}$ & 480 & 480 & 500 \\
\hline 15. & $\begin{array}{l}\text { łącznej mocy zainstalowanej elektrycznej większej niż } 1 \mathrm{MW} \\
\text { wykorzystujących wyłącznie hydroenergię do wytwarzania energii } \\
\text { elektrycznej }\end{array}$ & 480 & 480 & 480 \\
\hline 16. & $\begin{array}{l}\text { wykorzystujących wyłącznie energię geotermalną do wytwarzania energii } \\
\text { elektrycznej }\end{array}$ & 455 & 455 & 455 \\
\hline 17. & $\begin{array}{l}\text { łącznej mocy zainstalowanej elektrycznej nie większej niż } 1 \mathrm{MW} \text {, } \\
\text { wykorzystujących wyłącznie energię promieniowania słonecznego do } \\
\text { wytwarzania energii elektrycznej }\end{array}$ & 465 & 450 & 420 \\
\hline 18. & $\begin{array}{l}\text { łącznej mocy zainstalowanej elektrycznej większej niż } 1 \mathrm{MW} \text {, } \\
\text { wykorzystujacych wyłącznie energię promieniowania słonecznego do } \\
\text { wytwarzania energii elektrycznej }\end{array}$ & 445 & 425 & 400 \\
\hline 19. & $\begin{array}{l}\text { wykorzystujących wyłącznie energię wiatru na morzu do wytwarzania energii } \\
\text { elektrycznej }\end{array}$ & 470 & 470 & 450 \\
\hline 20. & $\begin{array}{l}\text { hybrydowej instalacji odnawialnego źródła energii o łącznej mocy } \\
\text { zainstalowanej elektrycznej nie większej niż } 1 \mathrm{MW}\end{array}$ & 300 & 455 & 390 \\
\hline 21. & $\begin{array}{l}\text { hybrydowej instalacji odnawialnego źródła energii o łącznej mocy } \\
\text { zainstalowanej elektrycznej większej niż } 1 \mathrm{MW}\end{array}$ & 430 & 405 & 350 \\
\hline
\end{tabular}

Źródło: opracowanie na podstawie rozporządzenia Ministra Energii dnia 24 marca 2017 r. (Dz. U. z 2017 r. poz. 634) i projektu rozporządzenia ME z 14 listopada $2017 \mathrm{r}$. 
Według pierwotnej wersji ustawy OZE aukcje miały się odbywać oddzielnie dla poszczególnych koszyków technologicznych:

Koszyk 1 - ze stopniem wykorzystania całkowitej zainstalowanej mocy, niezależnie od źródła pochodzenia, wyższym niż $3504 \mathrm{MWh} / \mathrm{MW} / \mathrm{rok}$,

Koszyk 2 - wykorzystujących biodegradowalną część odpadów przemysłowych, komunalnych, pochodzenia roślinnego i zwierzęcego,

Koszyk 3 - w których emisja $\mathrm{CO}_{2}$ jest nie wyższa niż $100 \mathrm{~kg} / \mathrm{MWh}$, ze stopniem wykorzystania całkowitej zainstalowanej mocy wyższej niż $3504 \mathrm{MWh} / \mathrm{MW} /$ rok

Koszyk 4 - dla energii wytworzonej przez członków klastra energii,

Koszyk 5 - dla energii wytworzonej przez członków spółdzielni energetycznej

Koszyk 6 - dla podmiotów wykorzystujących wyłącznie biogaz rolniczy do wytwarzania energii elektrycznej,

Koszyk - 7 - dla innych wymienionych w pkt. 1-6. (ustawa OZE 2015).

W ustawa o OZE znajdują się regulacje określające cenę referencyjną, która jest ustalana corocznie, za którą energia elektryczna z instalacji wykorzystujących odnawialne źródła energii jest sprzedawana w aukcji danego roku. Przy ustalaniu ceny referencyjnej dla 21 kategorii instalacji brane były pod uwage parametry techniczne i technologiczne, nakłady inwestycyjne związane z budową, sprawność wytwarzania energii, współczynnik wykorzystania dostępnej mocy, koszty operacyjne, przewidywane koszty cen paliw oraz ceny uprawnień do emisji $\mathrm{CO}_{2}$, wpływ instalacji na środowisko naturalne $\mathrm{i}$ in. (Uzasadnienie do rozporządzenia o cenach referencyjnych 2017). Wprowadzenie ceny referencyjnej oznacza, że oferty powyżej jej wartości będą automatycznie odrzucane, nawet, jeśli nie będzie innych ofert, co może skutkować brakiem osiagnięcia założonego dla danej aukcji celu w zakresie zakontraktowania odpowiedniego wolumenu energii (Ocena skutków regulacji 2017).

Oddzielną pozycją rozporządzenia o cenach referencyjnych są ceny dla instalacji nowych i modernizowanych po dniu wejścia w życie rozdziału 4 ustawy OZE. Propozycje cen referencyjnych dla aukcji na 2018 rok różnią się w stosunku do cen obowiązujących w 2017 roku w 11 z 21 grup technologii. W czterech przypadkach zaproponowano ceny wyższe, a w siedmiu przypadkach niższe. Zmiany te są konsekwencją urealnienia i dostosowania cen do rzeczywistych warunków rynkowych i po części elementem preferencyjnego traktowania wybranych technologii (na przykład instalacji wykorzystujących biogaz rolniczy).

Według projektu znowelizowanej Ustawy OZE z kwietnia 2018 roku wprowadzono łącznie 25 koszyków technologicznych dla instalacji nowych i 25 dla instalacji zmodernizowanych. Wydzielono w nich oddzielne pozycje dotyczące instalacji mniejszych niż $500 \mathrm{~kW}$ w technologiach produkcji biogazu. Przykładowe propozycje cen referencyjnych w złotych za $1 \mathrm{MWh}$, za jaką w 2018 r. może zostać sprzedana przez wytwórców w drodze aukcji energia elektryczna z odnawialnych źródeł energii wynoszą:

1) o łącznej mocy zainstalowanej elektrycznej mniejszej niż $500 \mathrm{~kW}$, wykorzystujących wyłącznie biogaz rolniczy do wytwarzania energii elektrycznej, wynosi 630 zł/MWh;

2) o łącznej mocy zainstalowanej elektrycznej mniejszej niż $500 \mathrm{~kW}$, wykorzystujących wyłącznie biogaz pozyskany ze składowisk odpadów do wytwarzania energii elektrycznej, wynosi $560 \mathrm{zt} / \mathrm{MWh}$;

3) o łącznej mocy zainstalowanej elektrycznej mniejszej niż $500 \mathrm{~kW}$, wykorzystujących wyłącznie biogaz pozyskany z oczyszczalni ścieków do wytwarzania energii elektrycznej, wynosi 420 zł/MWh; 
4) o łącznej mocy zainstalowanej elektrycznej mniejszej niż $500 \mathrm{~kW}$, wykorzystujących wyłącznie biogaz inny niż określony w pkt 2 i 3 do wytwarzania energii elektrycznej, wynosi $420 \mathrm{zt} / \mathrm{MWh}$;

5) o łącznej mocy zainstalowanej elektrycznej mniejszej niż $500 \mathrm{~kW}$, wykorzystujących wyłącznie hydroenergię do wytwarzania energii elektrycznej, wynosi 550 zł/MWh;

6) o łącznej mocy zainstalowanej elektrycznej nie mniejszej niż $500 \mathrm{~kW}$ i nie większej niż $1 \mathrm{MW}$, wykorzystujących wyłącznie biogaz rolniczy do wytwarzania energii elektrycznej, wynosi $570 \mathrm{zz} / \mathrm{MWh}$;

7) o łącznej mocy zainstalowanej elektrycznej większej niż $1 \mathrm{MW}$, wykorzystujących wyłącznie biogaz rolniczy do wytwarzania energii elektrycznej, wynosi 550 zł/MWh;

8) o łącznej mocy zainstalowanej elektrycznej nie mniejszej niż $500 \mathrm{~kW}$, wykorzystujących wyłącznie biogaz pozyskany ze składowisk odpadów do wytwarzania energii elektrycznej, wynosi $550 \mathrm{zł} / \mathrm{MWh}$;

9) o łącznej mocy zainstalowanej elektrycznej nie mniejszej niż $500 \mathrm{~kW}$, wykorzystujących wyłącznie biogaz pozyskany z oczyszczalni ścieków do wytwarzania energii elektrycznej, wynosi 385 zł/MWh;

10) o łącznej mocy zainstalowanej elektrycznej nie mniejszej niż $500 \mathrm{~kW}$, wykorzystujących wyłącznie biogaz inny niż określony w pkt 8 i 9 do wytwarzania energii elektrycznej, wynosi 385 zł/MWh;

Propozycje te są szczególnie korzystne dla inwestorów w biogazownie rolnicze do $500 \mathrm{~kW}$.

Są one następstwem zapisów zawartych w Strategii Odpowiedzialnego Rozwoju (SOR) zawierającej sformułowanie, że powinno się preferować instalacje zapewniające maksymalną dyspozycyjność oraz potrzeby lokalne związane z gospodarką odpadami i wykorzystaniem miejscowego potencjału. Ponadto w dywersyfikacji źródeł energii cieplnej, gazowej i elektrycznej, szczególnie na obszarach słabiej zurbanizowanych większy udział powinny mieć biogazownie rolnicze.

\section{Wyniki przebiegu aukcji w latach 2016-2017 w Polsce}

Nabór na pierwszą w Polsce aukcje został ogłoszony 30 listopada 2016 r. W rezultacie 30 grudnia 2016 r. skutecznie przeprowadzono 3 aukcje, jedna się nie odbyła z powodu zgłoszenia przez uczestników mniej niż 3 ważnych ofert spełniających wymagania określone $\mathrm{w}$ ustawie o odnawialnych źródłach energii. W aukcjach tych wzięli udział wytwórcy energii elektrycznej z biogazu rolniczego, instalacje fotowoltaiczne, wiatrowe i wodne do $1 \mathrm{MW}$ mocy. W pierwszym notowaniu do którego zgłosiło się 7 biogazowni, minimalna i maksymalna cena, po której sprzedawana była energia to odpowiednio 502,23 zł/MWh i 504,57 zł za MWh. Łączna ilość sprzedanej energii dla tej aukcji wyniosła $824629 \mathrm{GWh}$, a jej wartość 415,35 mln zł (Gostomczyk, 2017). W aukcji zwykłej nr AZ/3/2016 wygrały 84 projekty branży fotowoltaicznej złożone przez 62 wytwórców. W ramach tej aukcji zakontraktowano 1567 288,8 MWh energii za kwotę 554474 643,01 zł. Średni koszt sprzedanej energii wyniósł 353,79 zz/MWh, tj. ok. 24\% niżej od ceny referencyjnej (Aukcje OZE, 2017). W czwartej aukcji (AZ/4/2016), przewidzianej dla instalacji o mocy zainstalowanej elektrycznej nie większej niż $1 \mathrm{MW}$, spełniających kryteria stopnia wykorzystania mocy powyżej $3504 \mathrm{MWh} / \mathrm{MW} /$ rok oraz emisyjności nie większej niż $100 \mathrm{~kg} / \mathrm{MWh}$, czyli głównie elektrowni wodnych, aukcję wygrało wszystkie 49 skutecznie złożonych ofert, zgłoszonych przez 40 firm. Minimalna i maksymalna cena, 
po jakiej energia została sprzedana, to odpowiednio $30 \mathrm{zł} / \mathrm{MWh}$ i $468 \mathrm{zł} / \mathrm{MWh}$. Łącznie dla wszystkich technologii $\mathrm{w}$ grudniowej aukcji wygrało 140 ofert. Niska cena minimalna wynosząca $30 \mathrm{z}$ z/MWh jest możliwa tylko dla instalacji zamortyzowanych, które ponoszą głównie koszty eksploatacyjne, wykorzystujące energię natury.

Druga aukcja OZE została przeprowadzona 29 czerwca 2017 r. na podstawie ogłoszenia z dnia 29 maja 2017 r. Aukcja zwykła nr AZ/1/2017 obejmowała źródła fotowoltaiczne i wiatrowe a $\mathrm{nr}$ AZ/2/2017 małe elektrownie wodne. W pierwszej aukcji zostały wyłonione 352 zwycięskie projekty fotowoltaiczne i wiatrowe zgłoszone przez 236 podmiotów. Oznacza to ponad $300 \%$ wzrost podmiotów w stosunku do aukcji grudniowych. W ramach tej aukcji zakontraktowano $4720962 \mathrm{MWh}$ energii za kwote 1760121889 zł (99,9\% oferty). Średni koszt energii sprzedanej wynosił 373 zł/MWh (min. 195,00 zł i max. 398,87 zł/MWh). Na dwie czerwcowe aukcje wpłynęło 537 ofert z których 396 wygrało.

W roku 2017 planowano sprzedaż 1355,55 MWh energii elektrycznej o wartości 438,91 tys. zł, w kolejnym - 2018 roku 72 733,28 MWh o wartości 26,072 mln zł, a w ostatnim roku obowiązywania wsparcia (2035) przewiduje się sprzedaż $3242 \mathrm{MWh}$ za $1,037 \mathrm{mln}$ zł. Rekordowy ma być rok 2021, w którym przewidziano sprzedaż 321064,79 MWh energii za 119,713 mln zł (portal Gramwzielone.pl, 2017).

W aukcji migracyjnej dla elektrowni wodnych o mocy do $1 \mathrm{MW}$ przeprowadzonej w dniu 30 czerwca 2017 roku złożono skutecznie 44 oferty należące do 28 wytwórców. Ilość zgłoszonej energii wynosiła 1,484 TWh, a jej wartość 631,33 mln zł. Minimalna i maksymalna cena, po jakiej energia została sprzedana wyniosła odpowiednio $290 \mathrm{z} / \mathrm{MWh}$ i $474 \mathrm{zz} / \mathrm{MWh}$.

Kolejne aukcje miały się odbyć w dniach 28 września, 2 października, 4 października i 6 października i ogłoszone były dla koszyków technologicznych obejmujących biogazownie wysypiskowe i ściekowe do $1 \mathrm{MW}$, wodne do1 MW, biomasowe pow. $1 \mathrm{MW}$ i biogazownie rolnicze pow. $1 \mathrm{MW}$.

Tabela 3. Planowana ilość i wartość energii w aukcji 28.09-2-6.10. 2017 r.

Table 3. Planned amount and value of energy in the auction 28 September - 26 October, 2017

\begin{tabular}{c|cc}
\hline Termin aukcji & $\begin{array}{c}\text { Maksymalna ilość energii do sprzedaży } \\
{[\mathrm{MWh}]}\end{array}$ & $\begin{array}{c}\text { Maksymalna wielkość sprzedaży } \\
{[\mathrm{zl}]}\end{array}$ \\
\hline 28.09 .2017 & 1659047 & 556174673 \\
2.10 .2017 & 10502338 & 3768589370 \\
4.10 .2017 & 1149296 & 683370550 \\
6.10 .2017 & 2118162 & 1260181015 \\
Razem & 15428843 & 6268314608 \\
\hline
\end{tabular}

Źródło: opracowanie na podstawie biuletynu informacyjnego URE 2017.

W zaplanowanych terminach odbyła się tylko pierwsza aukcja, która w kolejnych dniach została odwołana. Odwołanie aukcji to rezultat zmiany dwóch rządowych rozporządzeń wynikających $\mathrm{z}$ braku rozwiązań zgodnych $\mathrm{z}$ unijnymi zasadami przyznawania pomocy publicznej, skutkującym tym, że do czasu wejścia w życie projektowanych zmian, nie powinny zostać rozstrzygnięte żadne kolejne aukcje. W rozporządzeniu nr 1819, rząd wyzerował ilość planowanej do zakupu energii (Inf. Prezesa URE nr 66/2017) ponieważ Komisja Europejska potraktowała ogłoszenie aukcji przed 
zakończeniem negocjacji jako złamanie prawa. Organizacja kolejnych aukcji wymagać będzie przyjęcia kolejnej nowelizacji ustawy o OZE.

Dla właściwego funkcjonowania systemu aukcyjnego niezbędne są trzy rozporządzenia:

1. W sprawie maksymalnej ilości i wartości energii z OZE sprzedawane w drodze aukcji,

2. W sprawie ceny referencyjnej dla poszczególnych koszyków technologicznych,

3. W sprawie daty i kolejności przeprowadzanych aukcji.

Brak aktów normatywnych i niestabilność prawa jest postrzegane przez przedsiębiorców jako ryzykowne miejsce lokalizacji inwestycji. Sprawa dotyczy dużych sum, ponieważ oszacowany koszt wsparcia w systemie aukcyjnym dla instalacji OZE w okresie 15 lat wyniesie 13 mld $377 \mathrm{mln} 843$ tys. 579 zł, co rocznie daje $743 \mathrm{mln} 213$ tys. 532 zł.

Czasu na realizacje aukcji i osiagnięcie zamierzonych celów wskaźnikowych pozostało już niewiele. Aby spełnić cele wskaźnikowe do 2020 roku należy zakontraktować nowe moce w OZE umożliwiające osiagnięcie $15 \%$ udziału. Z powodu długiej notyfikacji nowego systemu wsparcia wzrost produkcji energii elektrycznej ze źródeł OZE spowolnił. Przy oczekiwanym poziomie finalnego zużycia energii brutto w 2020 roku w wysokości 169-170 TWh i celu udziału OZE $15 \%$, zakontraktowana w aukcjach energia elektryczna z OZE powinna wynosić ok. 33 TWh. Odwołane aukcje w 2017 roku skutkują tym, że w pozostałych do 2020 roku latach rocznie powinno być zakontraktowane po 16-17 TWh energii. Przy obecnych tendencjach opóźnień można prognozować, że koszty koniecznego transferu wymaganej ilości energii z krajów które przekroczyły krajowe cele wskaźnikowe mogą spowodować obciążenie budżetu Polski kwotą ok. 17 mld zł.

Przedstawione zestawienie ukazuje duże zróżnicowanie cen uzyskiwanych w systemie aukcyjnym. Do najdroższych technologii należą instalacje wykorzystujące biomasę i biogaz. W wielu krajach koszty pozyskania energii słonecznej i wiatrowej są porównywalne i należą do najniższych $\mathrm{w}$ grupie OZE. Przegląd cen uzyskiwanych w aukcjach wskazuje, że na ich wysokość w dużym stopniu wpływa położenie geograficzne, szczególnie w przypadku energii słonecznej. Dlatego każdy kraj powinien preferować źródła pozwalające wytworzyć energię przy jak najniższym koszcie jednostkowym.

\section{Charakterystyka systemu aukcyjnego w Niemczech}

W przypadku energii odnawialnej bardzo dużo możemy nauczyć się od naszego zachodniego sąsiada, czyli Niemiec. Kraj ten od wielu lat stosuje skuteczne instrumenty wspierania odnawialnych źródeł energii, osiagając jednocześnie wymierne rezultaty. Ponadto analiza niemieckiej polityki wspierania OZE pozwala na uniknięcie części błędów, które zostały popełnione, przy równoczesnym wykorzystaniu mechanizmów charakteryzujących się wysoką efektywnością. Częścią nowej polityki jest przyjęcie 8 lipca 2014 roku przez parlament niemiecki nowelizacji ustawy o OZE w ramach której najpóźniej od 2017 roku dotychczasowy system wsparcia ma zostać zastąpiony systemem aukcyjnych dla większości technologii. Nowy system został oparty na następujących zasadach:

1. System aukcyjny obejmuje energię wiatrową na lądzie i morzu, instalacje fotowoltaiczne o mocy zainstalowanej większej niż $750 \mathrm{~kW}$ oraz instalacje na biomasę o mocy większej niż $150 \mathrm{KW}$; wyłączone $\mathrm{z}$ aukcji są małe instalacje fotowoltaiczne, geotermia oraz energia wodna,

2. Prawo do wsparcia przysługuje instalacjom, których oferty wygrały aukcję, 
3. Aukcje organizuje Federalna Agencja Sieci,

4. Dla każdej technologii aukcjonowana jest konkretna ilość mocy i odpowiednia wielkość wsparcia,

5. Wsparcie otrzymają oferty zawierające najniższą cenę,

6. Projekty, które otrzymają wsparcie będą musiały być zrealizowane w ciągu ustalonego okresu, w innym wypadku uiszczona musi być opłata karna (Przyszłość energetyki 2017).

Tabela 4. Przykłady krajów, które przeprowadziły aukcje OZE w 2016 roku

Table 4. Examples of countries that carried out RES auctions in 2016

\begin{tabular}{|c|c|c|c|}
\hline Kraj & Moc & Źródło energii & Cena \\
\hline \multirow{3}{*}{ Kanada } & $299,5 \mathrm{MW}$ & Wiatr & 66,9 USD/MWh \\
\hline & $140 \mathrm{MW}$ & Słońce & 120,0 USD/MWh \\
\hline & $15,5 \mathrm{MW}$ & woda & 137,5 USD/MWh \\
\hline USA & $26 \mathrm{MW}$ & Słońce & $37,0 \mathrm{USD} / \mathrm{MWh}$ \\
\hline \multirow{6}{*}{ Meksyk } & Pierwsza aukcja & & \\
\hline & 394 MW & Wiatr & 55,3 USD/MWh \\
\hline & 1,691 MW & Słońce & 45,1 USD/MWh \\
\hline & Druga aukcja & & \\
\hline & $1,038 \mathrm{MW}$ & Wiatr & 35,8 USD/MWh \\
\hline & $1,853 \mathrm{MW}$ & Słońce & 31,8 USD/MWh \\
\hline \multirow{4}{*}{ Peru } & $162 \mathrm{MW}$ & Wiatr & 37,7 USD/MWh \\
\hline & $184,5 \mathrm{MW}$ & Słońce & 48,1 USD/MWh \\
\hline & $80 \mathrm{MW}$ & Woda & 43,8 USD/MWh \\
\hline & $4 \mathrm{MW}$ & Biomasa & 77,0 USD/MWh \\
\hline \multirow{2}{*}{ Chile } & $1,5 \mathrm{MW}$ & Wiatr & 45,3 USD/MWh \\
\hline & $300 \mathrm{MW}$ & Słońce & $37,8 \mathrm{USD} / \mathrm{MWh}$ \\
\hline \multirow{2}{*}{ Brazylia } & $505 \mathrm{MW}$ & Woda & 56,7 USD/MWh \\
\hline & $198 \mathrm{MW}$ & Biomasa & 66,4 USD/MWh \\
\hline \multirow{7}{*}{ Argentyna } & Pierwsza aukcja & & \\
\hline & $707 \mathrm{MW}$ & Wiatr & 59,4 USD/MWh \\
\hline & $400 \mathrm{MW}$ & Słońce & 59,7 USD/MWh \\
\hline & 1,2 MW & Biogaz & $118,0 \mathrm{USD} / \mathrm{MWh}$ \\
\hline & Druga aukcja & & \\
\hline & $766 \mathrm{MW}$ & Wiatr & 53,3 USD/MWh \\
\hline & $518 \mathrm{MW}$ & Słońce & 54,9 USD/MWh \\
\hline \multirow{4}{*}{ Włochy } & $800 \mathrm{MW}$ & Wiatr na lądzie & 69,3 USD/MWh \\
\hline & $30 \mathrm{MW}$ & Wiatr na morzu & 169,8 USD/MWh \\
\hline & 19,8 MW & Geotermia & 86,4 USD/MWh \\
\hline & $20 \mathrm{MW}$ & Biomasa & 118,5 USD/MWh \\
\hline \multirow{2}{*}{ Dania } & $950 \mathrm{MW}$ & Wiatr na morzu & 60,4 USD/MWh \\
\hline & $21,6 \mathrm{MW}$ & Słońce & 19,9 USD/MWh \\
\hline Holandia & $1,4 \mathrm{MW}$ & Wiatr na morzu & 68,9 USD/MWh \\
\hline Federacja Rosyjska & $610 \mathrm{MW}$ & Wiatr & Brak danych \\
\hline Chiny & $1,0 \mathrm{MW}$ & Słońce & $77.9 \mathrm{USD} / \mathrm{MWh}$ \\
\hline Indie & $6,8 \mathrm{MW}$ & Słońce & 71,4 USD/MWh \\
\hline \multirow{2}{*}{ Monako } & $850 \mathrm{MW}$ & Wiatr & $30 \mathrm{USD} / \mathrm{MWh}$ \\
\hline & $170 \mathrm{MW}$ & Słońce & $60 \mathrm{USD} / \mathrm{MWh}$ \\
\hline \multirow{2}{*}{$\begin{array}{l}\text { Zjednoczone Emiraty } \\
\text { Arabskie }\end{array}$} & $800 \mathrm{MW}$ & Słońce & 29,9 USD/MWh \\
\hline & $1,17 \mathrm{MW}$ & Słońce & 24,2 USD/MWh \\
\hline Zambia & $73 \mathrm{MW}$ & Słońce & 67,4 USD/MWh \\
\hline
\end{tabular}

Źródło: opracowanie na podstawie: Renewable energy action, analysing 2016, IRENA 2017. 


\section{Aukcje w krajach UE i na świecie}

Polska nie jest pierwszym w Unii Europejskim krajem wdrażającym system aukcyjny. Takie działania wcześniej podjęte zostały m.in. w takich krajach jak Francja, Wielka Brytania, Holandia, Włochy, Grecja i Niemcy. Poza Unią Europejską system aukcyjny stosowany jest w USA, Kanadzie, Meksyku, Peru, Brazylii, Argentynie, Chile, Chinach, Indiach, Maroku, Zjednoczonych Emiratach Arabskich i in.

W Niemczech w systemie aukcyjnych uczestniczą głównie farmy wiatrowe i fotowoltaiczne. Ceny energii wiatrowej w poszczególnych aukcjach różnią się. Przeciętna cena w pierwszych przeprowadzonych aukcjach w 2015 roku wynosiła 57,1 EUR/MWh (najniższa oferta 42 EUR/MWh, a najwyższa $57,8 \mathrm{EUR} / \mathrm{MWh}$ ). Najniższe ceny były na listopadowej aukcji w 2017 roku. W ramach tej aukcji ceny zwycięskich ofert wynosily zaledwie od 22 EUR/MWh do 38,3 EUR/MWh. W 2017 roku Niemcy rozstrzygnęli również pierwszą $\mathrm{z}$ aukcji dedykowanych morskiej energetyce wiatrowej, w której inwestorzy zaoferowali sprzedaż energii bez dodatkowych premii oferując cenę 0 EUR/MWh, co oznacza, że energia będzie sprzedawana wyłącznie na warunkach rynkowych. Ceny ofert w lutowej (2018) aukcji wyłącznie dla farm fotowoltaicznych wyniosły średnio 43,3 EUR/MWh i wahały się w przedziale min. 38,6 EUR/MWh i max. 45,9 EUR/MWh.

Tabela 5. Zakontraktowane moce i ilość uczestników w aukcjach instalacji solarnych w Niemczech w latach 20152017

Table 5. Contracted capacity and number of participants in auctions of solar installations in Germany in 2015 2017

\begin{tabular}{|c|c|c|c|c|}
\hline Data aukcji & $\begin{array}{c}\text { Zakontraktowana moc } \\
{[\mathrm{MW}]}\end{array}$ & Liczba zwycięzców & Oferowana moc & Liczba zgłoszeń \\
\hline Kwiecień 2015 & 150 & 25 & 700 & 170 \\
\hline Sierpień 2015 & 150 & 33 & 558 & 136 \\
\hline Grudzień 2015 & 200 & 43 & 562 & 127 \\
\hline Kwiecień 2016 & 125 & 21 & 540 & 108 \\
\hline Sierpień 2016 & 130 & 25 & 311 & 63 \\
\hline Grudzień 2016 & 160 & 27 & 423 & 97 \\
\hline Luty 2017 & 200 & 38 & 488 & 97 \\
\hline
\end{tabular}

Źródło: opracowanie na podstawie: Renewable energy action, analysing 2016, IRENA 2017.

Częstotliwość przeprowadzanych aukcji i liczba zgłoszeń wskazuje, że niemiecki system aukcyjny jest skuteczny, sprawny i efektywny. Duża liczba zgłoszeń skutkuje większą konkurencją pomiędzy ofertami, co przekłada się na niższe koszty energii. Dodatkowym czynnikiem obniżki kosztów jest, że zakontraktowana energia będzie sprzedawana za kilka lat, co przy wysokim postępie technologicznym, zwłaszcza w zakresie fotowoltaiki i farm morskich czyni te technologie bardziej konkurencyjne. Eksperci z Niemiec obawiają się jednak, że przedkładane oferty nie zawierają wszystkich kosztów co może spowolnić lub nawet zahamować rozwój OZE. Dlatego w wybranych technologiach w aukcjach dla OZE przyjęto dwa modele płatności:

1. Tzw. Pay-as-bid, zgodnie z którym zwycięzcy aukcji zagwarantują sobie sprzedaż energii po cenie, którą zaoferowali w aukcji, 
2. Tzw. Uniform pricing, w którym zwycięskie projekty otrzymują cenę za energię, która odpowiada cenie najdroższej, zakwalifikowanej do realizacji oferty (Renewable energy actions 2017).

Drugi model jest pewnym odstępstwem od zasady, że wygrywający uzyskuje zaproponowaną cenę, ale zapobiega ich nieuzasadnionemu zróżnicowaniu, czyniąc je bardzie realne rynkowo. Podraża to koszty systemu, ale zapewnia stabilny przyrost mocy.

\section{Planowane w 2018 roku aukcje ich wolumen i wartość energii}

Dostosowanie porządku prawnego do nowego systemu aukcyjnego wymusza jego zmiany. W projekcie nowelizacji ustawy o OZE (druk sejmowy 2412) wprowadza się nowy podział na tzw. koszyki aukcyjne:

\section{Koszyk nr 1}

- instalacje wykorzystujące wyłącznie biogaz pozyskany ze składowisk odpadów,

- instalacje wykorzystujące wyłącznie biogaz pozyskany z oczyszczalni ścieków,

- instalacje wykorzystujące wyłącznie biogaz inny niż określony w pkt. 1 i 2 powyżej,

- instalacje dedykowane spalaniu biomasy lub układów hybrydowych

- instalacje wykorzystujące wyłącznie biomasę, biopłyny, biogaz lub biogaz rolniczy

spalany w dedykowanej instalacji spalania wielopaliwowego,

- instalacje dedykowane wyłącznie spalaniu biomasy lub układów hybrydowych,

w wysokosprawnej kogeneracji.

\section{Koszyk nr 2}

- instalacje wykorzystujące wyłącznie hydroenergię do wytwarzania energii elektrycznej

- instalacje wykorzystujące wyłącznie energię geotermalną do wytwarzania energii

elektrycznej,

- instalacje wykorzystujące wyłącznie energię wiatru na morzu.

\section{Koszyk nr 3.}

- instalacje wykorzystujące wyłącznie biogaz rolniczy

Koszyk nr 4.

- instalacje wykorzystujące wyłącznie energię wiatru na lądzie

- instalacje wykorzystujące wyłącznie energię promieniowania słonecznego.

Koszyk nr 5 dla hybrydowych instalacji OZE.

Nowością nowelizacji to także wpisanie bezpośrednio do ustawy o OZE wolumenu i wartości energii, które rząd będzie chciał zakupić w tegorocznych aukcjach (2018) (wcześniej takie wartości były określane w rozporządzeniach). W przypadku aukcji migracyjnych dla instalacji o mocy do $1 \mathrm{MW}$, w których wytwarzanie energii rozpoczęto w systemie zielonych certyfikatów, a więc przed 1 lipca 2016 r., w tym roku przewiduje się aukcje wyłącznie dla koszyków 1-3. Dla pierwszego koszyka Ministerstwo Energii przewiduje zakup $915336 \mathrm{MWh}$ energii elektrycznej o wartości nieprzekraczającej 403 207920 zł. Dla drugiego - zakup 1475211 MWh za maksymalnie 737605600 zł. Dla trzeciego - 1149296 MWh za maks. 655098834 zł. W grupie istniejących instalacji o mocy ponad $1 \mathrm{MW}$ przewiduje się na podstawie tegorocznych aukcji migracyjnych zakup energii z pierwszego i trzeciego koszyka. W pierwszym Ministerstwo Energii przewiduje zakup 3864470 MWh za maks. 14203623881 zl, a w trzecim - 1467617 MWh za maks. $807189350 \mathrm{zl}$. 
W przypadku nowych instalacji, z których rozpoczęcie produkcji energii nastąi po raz pierwszy po dniu wygrania aukcji, dla instalacji o mocy do $1 \mathrm{MW}$ przewiduje się w tym roku zakup energii z wszystkich pięciu koszyków. Dla koszyka pierwszego przewidziano zakup 14700000 MWh za maks. 6191250000 zł. Dla koszyka drugiego przewiduje się zakup $3750000 \mathrm{MWh}$ za maksymalnie 1895250000 zł. W koszyku trzecim wsparcie na postawie tegorocznych aukcji może objąć energię w ilości 11700000 MWh i wartości 7 $160400000 \mathrm{zł}$. Z kolei czwarty koszyk - wiatrowo-fotowoltaiczny - powinien w tym roku dać możliwość sprzedaży 16065000 MWh energii elektrycznej o wartości 6240300000 zł. W tym przypadku Ministerstwo Energii prognozuje objęcie wsparciem elektrowni fotowoltaicznych o mocy nawet $750 \mathrm{MW}$ (cena referencyjna $420 \mathrm{z} / \mathrm{MWh}$ ) oraz mniejszych elektrowni wiatrowych do $120 \mathrm{MW}$ (cena referencyjna $320 \mathrm{zz} / \mathrm{MWh}$ ). Natomiast koszyk piąty, czyli „hybrydowy”, to możliwość sprzedaży 1140000 MWh za maksymalnie 473700100 zł. ME zakłada, że wsparcie może objąc instalacje hybrydowe o mocy do 20 MW (cena referencyjna $415 \mathrm{zz} / \mathrm{MWh}$ ).

W przypadku nowych instalacji, z których rozpoczęcie produkcji energii nastąpi po raz pierwszy po dniu wygrania aukcji, dla instalacji o mocy powyżej $1 \mathrm{MW}$ przewiduje się w tym roku zakup energii również z wszystkich pięciu koszyków. Na koszyk pierwszy przewidziano zakup w tegorocznych aukcjach $21000000 \mathrm{MWh}$ energii elektrycznej o wartości 7770000000 zł. Na koszyk drugi przewidziano $5400000 \mathrm{MWh}$ o maks. wartości 2592000000 zł. W trzecim koszyku może zostać sprzedane $7020000 \mathrm{MWh}$ energii elektrycznej o wartości 3861000 zł. Najwięcej energii rząd może zakupić w koszyku czwartym, dając szansę na realizację dużych inwestycji wiatrowych, dla których przewidziano maks. $45000000 \mathrm{MWh}$ o wartości $15750000000 \mathrm{zł}$. W tym przypadku Ministerstwo Energii prognozuje objęcie wsparciem farm wiatrowych o mocy nawet $1 \mathrm{GW}$ (cena referencyjna $350 \mathrm{z} / \mathrm{MWh}$ ). Nie przewiduje się natomiast wygrania aukcji przez inwestorów planujących większe elektrownie fotowoltaiczne o mocy ponad $1 \mathrm{MW}$ (cena referencyjna $400 \mathrm{zł} / \mathrm{MWh}$ ). W koszyku piątym możliwy jest w tym roku zakup energii z instalacji hybrydowych w ilości do 10260000 MWh przy wartości maks. 4206600000 zł. Ministerstwo Energii zakłada, że wsparcie może objać instalacje o mocy do $180 \mathrm{MW}$ (cena referencyjna $410 \mathrm{z} / \mathrm{MWh}$ ). W projekcie ustawy o OZE nie przewidziano natomiast na ten rok zakupu energii w drodze aukcji dla instalacji zmodernizowanych. Nowy zapis to także warunek, zgodnie z którym aukcję mają wygrywać oferty, w przypadku których nie przekroczono maksymalnej wartości energii elektrycznej z odnawialnych źródeł energii określonej w ogłoszeniu o aukcji i 80 proc. ilości tej energii elektrycznej. Maksymalną wartość i ilość energii elektrycznej, którą rząd ma zakupić w aukcjach w 2019 roku, ma wskazać rozporządzenie Rady Ministrów.

Według stanu prawnego obowiązującego na początku 2017 roku, nie uwzględniającego jeszcze restrykcji Unii Europejskiej dotyczących braku uregulowań wynikających z udzielania pomocy publicznej Ministerstwo Energii sporządziło prognozą potencjału zakontraktowanych mocy w aukcjach w 2018 roku z podziałem na poszczególne technologie (rys. 1). Największą pulę przewidziano dla instalacji wykorzystujących energię wiatru na lądzie o mocy powyżej $1 \mathrm{MW}$, której łączna moc miała osiągnąc poziom 1000 MW i fotowoltaika o jednostkowej zainstalowanej mocy poniżej 1 MW pozwalająca wytworzyć 750 MW. Wysoki udział zaplanowano również dla technologii wykorzystujących biogaz (rolniczy, składowiskowy i ściekowy), dla którego łączna zakontraktowana moc w aukcjach w 2018 roku miała osiągnąc 300 MW. 


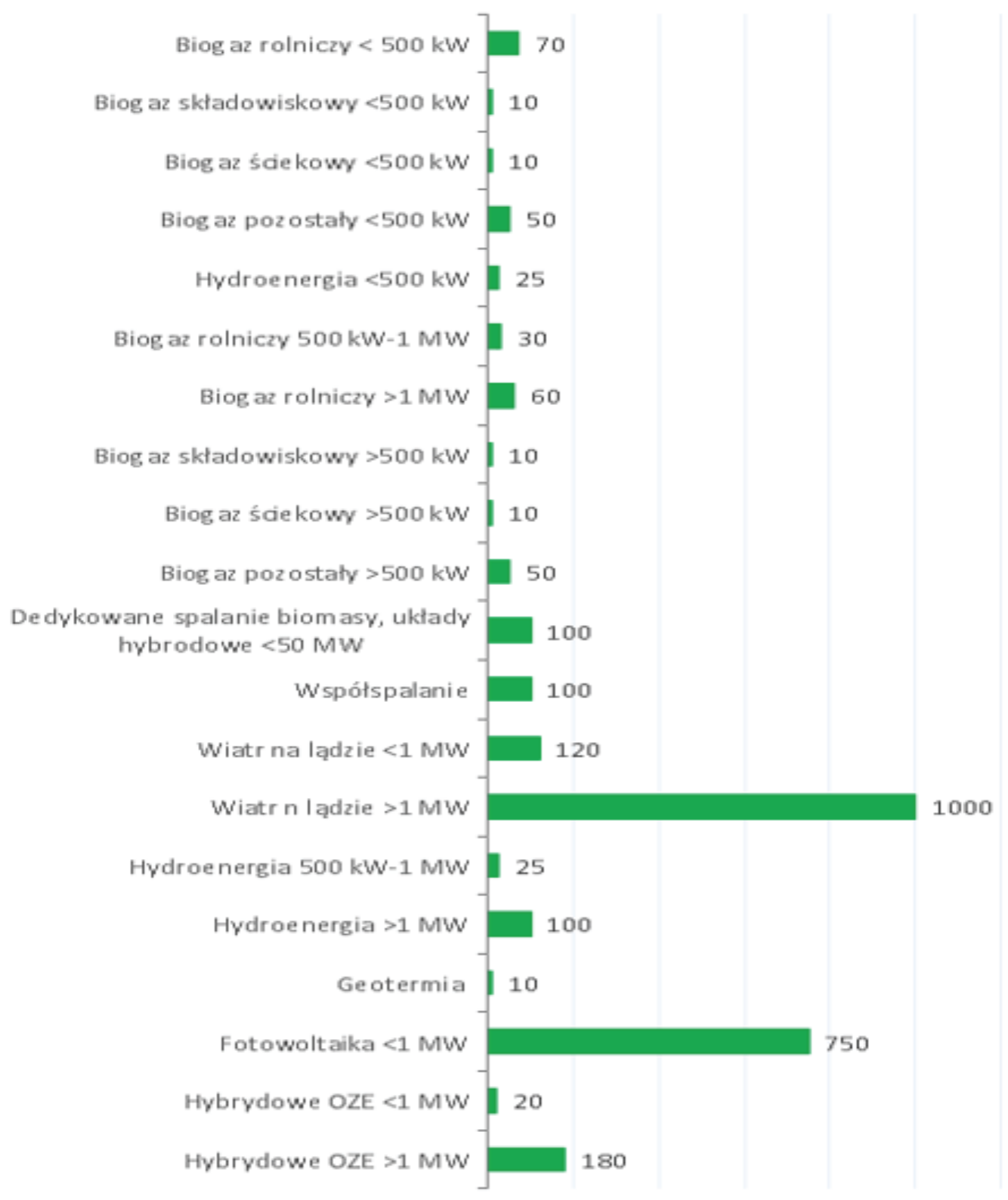

Rys. 1. Prognozowany przez Ministerstwo Energii potencjał zakontraktowanych mocy w aukcjach w 2018 roku $\mathrm{z}$ podziałem na poszczególne technologie (dane w MW)

Fig 1. Forecasted by the Ministry of Energy the potential of contracted capacity in auctions in 2018 divided into individual technologies (data in MW)

Źródło: Projekt rozporządzenia ME z 14 listopada 2017 r. w sprawie cen referencyjnych w 2018 r. 
W związku z procesem notyfikacji programu „Polski system wsparcia dla odnawialnych źródeł oraz ulg dla odbiorców energochłonnych, S.A.43697 (2015/N)" konieczne są zmiany w regule kumulacji łącznej pomocy uzyskanej przez wytwórców energii elektrycznej z OZE oraz w mechanizmie zapewnienia konkurencyjności składanych ofert aukcyjnych. Zmiany te, które uzyskały aprobatę UE muszą być częścią nowelizacji ustawy o OZE oraz wydanych na jej podstawie rozporządzeń. Do I połowy 2018 roku Sejm RP ich jeszcze nie zatwierdził a do czasu wejścia w życie projektowanych zmian żadne kolejne aukcje nie mogą być rozstrzygnięte. Rodzi to poważne obawy czy prognozowany przez Ministerstwo Energii zakontraktowany potencjał mocy w aukcjach 2018 roku zostanie zrealizowany.

\section{Podsumowanie}

Pomimo krótkiego okresu funkcjonowania systemu aukcyjnego można poczynić próby jego oceny. Sam fakt przechodzenia inwestorów z systemu zielonych certyfikatów do systemu aukcyjnego świadczy o jego pozytywnej ocenie. Nowy system gwarantuje przede wszystkim stabilność wsparcia, czego brakowało szczególnie od roku 2012 w starym systemie zielonych certyfikatów. Inwestor wygrywający aukcje zna przez okres 15 lat wartość wsparcia niezależnie od warunków rynkowych. W nowym systemie państwo uzyskuje kontrolę w zakresie sterowania wielkością wzrostu produkcji energii odnawialnej. Skutecznie ogłoszone i przeprowadzone aukcje mogą zapewnić wymagany corocznie wzrost produkcji prowadzący do realizacji Narodowych Celów Wskaźnikowych. Poprzez aukcje dedykowane można te cele osiągnąć niższym kosztem, zgodnie z zasadą że system z założenia powinien być zorientowany na konkurencje między wytwórcami energii. Prokonkurencyjna konstrukcja mechanizmu aukcyjnego powinna w konsekwencji doprowadzić do redukcji wydatków na wsparcie OZE. Zróżnicowanie poziomu wsparcia różnych technologii $\mathrm{w}$ postaci cen referencyjnych, szczególnie w początkowym okresie pozwoli na rozwój technologii „drogich”, które rokują w przyszłości znaczą obniżką kosztów. Przykładem mogą być fotoogniwa, których ceny corocznie spadaja przy jednoczesnym wzroście ich efektywności. Taka polityka pozwoli w przyszłości handlować energią odnawialną na warunkach rynkowych, bez potrzeby wsparcia. Konkurencyjny charakter aukcji może w przyszłości tworzyć problemy, które spowodują, że rzeczywista produkcja będzie mniejsza od oczekiwanej. Ryzyko wystapienia tego zjawiska określanego jako underbidding występuje w niektórych krajach zachodnich, w których zbudowano jedynie niewielki procent zakontraktowanych w aukcjach mocy (Polsce grozi..., 2016). Polski system prawny przewiduje kary za niewykonanie warunków umowy dla wygrywających aukcje, co powinno zapobiegać tego typu sytuacjom.

Istnienie odpowiedniego systemu wsparcia jest niezbędne aby energetyka odnawialna mogła konkurować z energetyką konwencjonalną. Warunki konkurencji nie zawsze sa równe. Wynika to z faktu, że większość elektrowni węglowych jest już zamortyzowanych (ze względu na wiek) oraz w ostatecznych rachunku kosztów nie uwzględnia się kosztów zewnętrznych. Pomimo, że system aukcyjny w Polsce funkcjonuje bardzo krótko to już widać efekty w poprawie opłacalności tego sektora. Wyraża się to wzrostem cen zielonych certyfikatów, spowodowanym przejściem części instalacji ze starego systemu do nowego w ramach aukcji migracyjnych. Ostateczne rezultaty wdrażanego systemu aukcyjnego będą możliwe do oceny dopiero za kilka lat. Podstawowym warunkiem jego powodzenia jest 
stworzenie i praktyczne wdrożenie trwałych i stabilnych instrumentów prawnych, które dla inwestorów są podstawą podejmowania decyzji o strukturze i mocy budowanych instalacji OZE. Skuteczność mechanizmu aukcyjnego można ocenić na podstawie wzrostu zainteresowania inwestorów w technologie odnawialne, wynikające $\mathrm{z}$ opłacalności oraz obniżki kosztów pomocy publicznej pozwalającej osiagać zamierzone cele związane ze wzrostem ilości OZE w miksie energetycznym, tj. procentowym udziałem energii odnawialnej w całkowitej produkcji energii brutto. Wartość ta jest określona jako Narodowy Cel Indykatywny, który Polska ma zrealizować do roku 2020.

Pogłębiona analiza funkcjonowania systemu aukcyjnego w Polsce na podstawie stanu obecnego jest bardzo ograniczona. Za mało przeprowadzono skutecznych aukcji, nie wiadomo jak zadziałają nowe mechanizmy po pokonaniu ograniczeń prawnych i organizacyjnych. Skuteczność systemu aukcyjnego w państwach zachodnich pozwala prognozować, że również w Polsce z czasem pozwoli skutecznie realizować cele związane z wykorzystaniem odnawialnych źródeł energii.

\section{Literatura}

Aukcje OZE - fotowoltaika. (RES auctions - photovoltaic), IEO, Warszawa 2017.

Czysta energia (Clean energy) - nr 1/2016.

Energia ze źródeł odnawialnych w 2016 r. (Energy from renewable sources in 2016), GUS Warszawa 2017.

Energia odnawialna: ważny uczestnik europejskiego rynku energii. (Renewable energy: a major player in the European energy market), (COM(2012)027).

Energy Statistic 2017 edition, Eurostat, Luxembourg 2017.

Energy balance sheets 2017 edition, Eurostat, Luxembourg 2017.

Gostomczyk, W. (2017). Stan i perspektywy rozwoju rynku biogazu w UE i Polsce - ujęcie ekonomiczne. (The state and prospects for the development of the biogas market in the EU and Poland - economic approach). Problemy Rolnictwa Światowego, 17(2), 48-64.

Informator Federalnej Agencji Bundesnetzagentur - BnetzA (Guide of the Federal Agency Bundesnetzagentur), 2017.

Ocena skutków regulacji (2017) projektu rozporządzenia ME w sprawie ceny referencyjnej na 2018 r. (Regulatory Impact Assessment (2017) of the draft ME Regulation on the reference price for 2018, (70.1.17)

Polsce grozi scenariusz holenderski. (Poland is threatened by the Dutch scenario), interia.pl dostęp 23.01.2016 r.

Portal Gramwzielone.pl

Projekt nowelizacji ustawy o OZE. (Draft amendment to the RES Act), (druk sejmowy 2412 z kwietnia 2018).

Polski system wsparcia dla odnawialnych źródeł oraz ulg dla odbiorców energochłonnych. (Polish support system for renewable sources and allowances for energy-consuming customers), S.A.43697 (2015/N).

Przyszłość energetyki odnawialnej w Niemczech - stały trend, nowe zasady. (The future of renewable energy in Germany - a constant trend, new rules), Heinrich Boll Stiftung, Warszawa 2017.

Projekt rozporządzenia ME z 14 listopada 2017 r. w sprawie cen referencyjnych w 2018 r. (The draft regulation of the ME of November 14, 2017 on reference prices in 2018)

Raport WiseEuropa (2017). Ukryty rachunek za węgiel 2017. (Report WiseEuropa 2017, Hidden Bill for Coal 2017), Warszawa.

Renewable energy action, analysing 2016, IRENA 2017.

Regulamin Aukcji na sprzedaż energii elektrycznej wytwarzanej w instalacjach odnawialnego źródła energii. (Auction Regulations for the sale of electricity generated in renewable energy installations), Warszawa URE, 2016.

Rynek aukcji OZE - raport IEO. (RES auction market - IEO report), Warszawa- ieo.pl/aktualności, dostęp 201802-15.

Stan energetyki wiatrowej w Polsce w 2016 roku. (The state of wind energy in Poland in 2016), PSEW, Warszawa czerwiec 2017.

Wytyczne w sprawie pomocy państwa na ochronę środowiska i cele związane z energią w latach 2014-2020. (Guidelines on State aid for environmental protection and energy related objectives in 2014-2020), (2014/C 200/01) (Dz. Urz. UE seria C, nr 200, s. 1). 
Uzasadnienie do rozporządzenia o cenach referencyjnych na $2018 \mathrm{r}$. (Justification to the reference price regulation for 2018), ME (2017).

Ustawa z dnia 20 lutego 2015 r. o odnawialnych źródłach energii. (The Act of 20 February 2015 on renewable energy sources), (Dz. U. 2015, poz. 478, z późn. zm.).

Ustawa o odnawialnych źródłach energii. (Act on renewable energy sources). (Dz. U. 2017, poz. 1148, 1213, 1593)

Do cytowania / For citation:

Gostomczyk W. (2018). System aukcyjny jako nowy sposób wspierania OZE. Problemy Rolnictwa Światowego, 18(3), 113-133; DOI: 10.22630/PRS.2018.18.3.71

Gostomczyk W. (2018). The Auction System as a New Way to Promote Renewable Energy (in Polish). Problems of World Agriculture, 18(3), 113-133; DOI: 10.22630/PRS.2018.18.3.71 